Crop Breeding and Applied Biotechnology 12: 215-219, 2012

Brazilian Society of Plant Breeding. Printed in Brazil

NOTE

\title{
Heritability and correlation among potato tuber traits
}

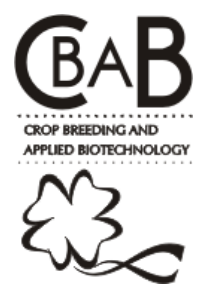

Dilson Antonio Bisognin ${ }^{1 *}$, Maria Helena Rigão ${ }^{2}$, Sidinei José Lopes ${ }^{1}$ and Lindolfo Storck ${ }^{1}$

Received 23 August 2010

Accepted 8 February 2011

\begin{abstract}
The objectives were to estimate variance, co-variance and heritability components of potato tuber shape and fresh weight and the correlation among these traits in the early generations of selection. Seed and harvested tubers of nine progeny were evaluated for length, larger and smaller diameter and fresh weight. In average, the tubers were lengthy, because the relationship between lenght with larger diameter was 1.30 and with smaller diameter was 1.51. High heritability estimations were gotten for progeny selection, and low heritability for clone selection in the progeny. Heritability estimations got from correlation between generations were high and similar to progeny mean estimations. The tuber shape and fresh weight traits were highly correlated. The breeding gain can be maximized combining the selection among and within progeny to early discard undesirable clones.
\end{abstract}

Key words: Solanum tuberosum $L$., genetic variance, selection gain, potato breeding.

\section{INTRODUCTION}

Potato (Solanum tuberosum L.) is the fourth crop in the world, after wheat, rice and maize, with a production of 315.1 million tons in 2006 (http://www.fao.org/). In Brazil, potato is the most important horticultural crop, with 142,300 ha, producing 3.38 million of tons. The average was 23.7 $\mathrm{t} \mathrm{ha}^{-1}$ in 2007 (http://www.ibge.gov.br/home/). The main producing States are Minas Gerais, Paraná, São Paulo and Rio Grande do Sul, responsible for $87 \%$ of the nationwide production (http://www.ibge.gov.br/home/).

Potato is an asexually propagated crop by tubers, which are underground and modified stems. Tubers are also stock pile organs, mainly starch, and show dormancy right after harvesting. The dormancy level greatly varies among cultivars, growing and storage conditions and tuber physiological age at harvest (Beukema and Van Der Zaag 1990, Bisognin et al. 2008). Breaking dormancy is necessary in the first clone generations of selection, because of the limited number of small tubers, which have higher levels of dormancy (Beukema and Van Der Zaag 1990, Bisognin et al. 1998), to minimize clone discard, due to either no or late plantlet emergence.
In the potato breeding program, usually have a generation of tuber family production from botanic seeds, followed by generations of clone selection in the field. The first generation is usually in single-hill plots, followed by clone generations of plots with variable and increasing number of hills (Bisognin 2003) to phenotypic select clones. In the first generation of selection, a large number of clones can be discarded, which reduces costs and facilitate the identification of superior clones to introduce in the crossing block (Thill and Peloquin 1995). If the purpose is to combine characters by recurrent selection, an evaluation and selection strategy to identify desirable clones should be developed and applied as soon as possible in the breeding program (Bisognin and Douches 2002).

Evaluating clones in different generations of selection or growing conditions make possible to estimate genetic parameters, such as heritability and selection gain, to identify the best breeding strategy (Bisognin and Douches 2002). The breeding strategy can also be based upon the percentage of selected clones, the correlation between generations and the expected gain in different selection indexes. The ideal selection index to get a balance between the expected gain and the discard of valuable clones in any generation can be adjusted by simulations (Bisognin 2003).

\footnotetext{
${ }^{1}$ Universidade Federal de Santa Maria (UFSM), Departamento de Fitotecnia, Av. Roraima, 1000, 97.105-900, Camobi, Santa Maria, RS, Brazil. *E-mail: dilsonb@smail.ufsm.br

2 Universidade Federal de Santa Maria (UFSM), Departamento de Estatística, Av. Roraima, 1000, 97.105-900, Camobi, Santa Maria, RS, Brazil.
} 
The genetic parameters can also be estimated by components of variance. The expected mean squares can be gotten for a given model by deducing them from the expressions of mean squares and applying mathematical properties and assumptions made about the parameters of the model, or by using the modified Hicks method (Barbin 1998). The mean value of square (or mean products) with their mathematical assumptions are the estimations of variance (or covariance) components. These estimations can be used to compute the correlation coefficients and the heritability of a given trait (Vencovsky and Barriga 1992). The correlation estimations between traits indicate the possibility of indirect selection, which is also important to define the best breeding strategy.

The objectives were to estimate variance, covariance and heritability components of potato tuber shape and fresh weight and the correlation among these traits in the early generations of selection.

\section{MATERIAL AND METHODS}

The experiment was carried out in the experimental field of the Plant Science Department of the Federal University of Santa Maria (UFSM), in Santa Maria, Rio Grande do Sul State, Brazil. Clones representing nine progenies of the Potato Breeding and Genetics Program were evaluated. The first generation was planted on March $14^{\text {th }}, 2006$. One tuber of each harvested clone was planted on August $25^{\text {th }}$, 2006, for the second generation. The experiment of both generations was a random design, with one replication of a single-hill plot. Six harvested tubers of each clone of the second generation were planted on March $15^{\text {th }}, 2007$, for the third generation. The experiment was a random design, with two replications of three-hill plots.

All tuber seeds were sprayed with $30 \mathrm{mg} \mathrm{L}^{-1}$ of gibberellic acid (Benedetti et al. 2005), approximately 60 days prior planting, and stored at $25^{\circ} \mathrm{C}$ for dormancy breaking. One seed tuber was planted in each hill. The hills were $0.30 \mathrm{~m}$ apart in the row and $0.80 \mathrm{~m}$ between rows. At harvest, data was recorded separately for each hill. All seed and harvested tubers were evaluated for length (L), larger diameter (LD) and smaller diameters (SD) and fresh weight (FW). The following tuber relationships were estimated: $L L D=L /$ $\mathrm{LD}$ and $\mathrm{LSD}=\mathrm{L} / \mathrm{SD}$.

Data from third generation were used to estimate variances, covariances and its components. For data analysis, $\mathrm{J}=2$ replications, $\mathrm{I}=9$ progenies, $\mathrm{K}=3$ hills per plot, and $\mathrm{n}=$ number of harvested tubers per hill. The mathematical model was characterized by $\mathrm{Y}_{\mathrm{ijkl}}=\mathrm{m}+\mathrm{t}_{\mathrm{i}}+\mathrm{e}_{\mathrm{ij}}+\mathrm{d}_{\mathrm{k}(\mathrm{ij})}+\varepsilon_{1(\mathrm{ijk})}$; where $\mathrm{Y}_{\mathrm{ijk}}=$ the observed value of the tuber 1 of the hill $\mathrm{k}$ of the progeny $\mathrm{i}$ of the replication $\mathrm{j} ; \mathrm{m}=$ the average; $\mathrm{t}_{\mathrm{i}}=$ the random effect of the progeny $\mathrm{i} ; \mathrm{e}_{\mathrm{ij}}=$ the random effect of the experimental error $\mathrm{ij} ; \mathrm{d}_{\mathrm{k}(\mathrm{ij})}=$ the random effect of the hill $\mathrm{k}$ in the plot $\mathrm{ij}$; and $\varepsilon_{1(\mathrm{ijk})}=$ the random effect of the tuber 1 in the hill ijk. For the analysis of variance (Table 1 ), the number of the tubers per hill (n) and the number of the hills per plot were as a harmonic mean, considering the two replications.

Table 1. Summary of the variance analysis

\begin{tabular}{llll}
\hline Sources of variation & $\mathbf{d f *}$ & MS & E(MS) \\
\hline Progeny (g) & $\mathrm{I}-1$ & $\mathrm{Q} 1$ & $\sigma^{2}+n \sigma_{d}^{2}+n K \sigma_{e}^{2}+n J K \sigma_{g}^{2}$ \\
Error among plot (e) & $\mathrm{I}(\mathrm{J}-1)$ & $\mathrm{Q} 2$ & $\sigma^{2}+n \sigma_{d}^{2}+n K \sigma_{e}^{2}$ \\
Error among hill (d) & $\mathrm{IJ}(\mathrm{K}-1)$ & $\mathrm{Q} 3$ & $\sigma^{2}+n \sigma_{d}^{2}$ \\
Error within hill (u) & $\mathrm{IJK}(\mathrm{n}-1)$ & $\mathrm{Q} 4$ & $\sigma^{2}$
\end{tabular}

*J = number of replications; $\mathrm{I}=$ number of progenies; $\mathrm{K}=$ number of hills/plot; $\mathrm{n}=$ harmonic average of the number of tubers/hill.

Applying the Vencovsky and Barriga (1992) and Barbin (1998) expressions in this data set we got the estimations of variance among tubers within a hill $\left(\hat{\sigma}^{2}=Q 4\right)$; among hills $\left(\hat{\sigma}_{d}^{2}=(Q 3-Q 4) / n\right)$; among plots $\left(\hat{\sigma}_{e}^{2}=(Q 2-Q 3) /\right.$ $n K)$; among progenies $\left(\hat{\sigma}_{g}^{2}=(Q 1-Q 2) / n J K\right)$, where $\mathrm{Q} 1$, Q2, Q3 and Q4 were the mean squares as defined in table 1. With these components of variance we estimated the broad sense heritability $h_{i}^{2}=\hat{\sigma}_{g}^{2} /\left(\hat{\sigma}^{2}+\hat{\sigma}_{d}^{2+} \hat{\sigma}_{e}^{2+} \hat{\sigma}_{g}^{2}\right)$ for clone selection (clone level), and $\left\{\mathrm{h}_{m}^{2}=\hat{\sigma}_{g}^{2} /\left\{\left(\hat{\sigma}^{2} / n J K+\hat{\sigma}_{d}^{2} /\right.\right.\right.$ $\left.\left.J K+\hat{\sigma}_{e}^{2} / J+\hat{\sigma}_{g}^{2}\right)\right\}$ for progeny selection (progeny level).

For each of the traits (L, LD, SD, FW, LLD, and LSD) we estimated the mean coefficient of heritability $\left(\mathrm{h}_{m}^{2}\right)$ for average progeny selection. Also, we estimated the linear correlation coefficient between progeny averages of two consecutive generations (Bisognin and Douches 2002). Therefore, the average of the nine harvested progenies in the first generation was correlated with the same harvested progenies in the second generation $\left(\mathrm{r}_{12}\right)$, and between the second and the third generation $\left(\mathrm{r}_{23}\right)$.

With a data pair of any $\mathrm{x}$ and $\mathrm{y}$ characters we estimated the covariance among tubers ( $\left.\hat{\sigma}_{\mathrm{xy}}=\mathrm{MP} 4\right)$; among hills ( $\hat{\sigma}$ $\left.{ }_{\mathrm{dxy}}=(\mathrm{MP} 3-\mathrm{MP} 4) / \mathrm{n}\right)$; among plots $\left(\hat{\sigma}_{\mathrm{exy}}=(\mathrm{MP} 2-\mathrm{MP} 3) /\right.$ $\mathrm{nK})$; and among progenies $\left(\hat{\sigma}_{\mathrm{gxy}}=(\mathrm{MP} 1-\mathrm{MP} 2) / \mathrm{nJK}\right)$. The values of MP1, MP2, MP3 and MP4 corresponded to the mean products defined in Table 2. The estimations of variance and covariance components were used to estimate the linear correlation coefficients (Pearson) between all the pairs (x and y) of traits $\left(\mathrm{r}_{\mathrm{xy}}\right)$ with the expressions $r_{g x y}=\hat{\sigma}$ ${ }_{g x y} /\left(\hat{\sigma}_{g x} * \hat{\sigma}_{g y}\right)$, for progenies; $r_{e x y}=\hat{\sigma}_{e x y} /\left(\hat{\sigma}_{e x}{ }^{*} \hat{\sigma}_{e y}\right)$, for plots; $r_{d x y}=\hat{\sigma}_{d x y} /\left(\hat{\sigma}_{d x}{ }^{*} \hat{\sigma}_{d y}\right)$, for hills; and $r_{x y}=\hat{\sigma}_{x y} /\left(\hat{\sigma}_{x}{ }^{*}\right.$ $\left.\hat{\sigma}_{y}\right)$, for tubers. All the statistical analyses were done with the NTIA (Embrapa 1997) and Excel softwares. 
DA Bisognin et al.

Table 2. Summary of the covariance analysis

\begin{tabular}{llll}
\hline Sources of variation & $\mathbf{d f *}$ & MP & E(MP) \\
\hline Progeny (g) & $\mathrm{I}-1$ & MP1 & $\sigma_{\mathrm{xy}}+n \sigma_{\mathrm{dxy}}+n K \sigma_{e x y}+n J K \sigma_{g \mathrm{xy}}$ \\
Error among plot (e) & $\mathrm{I}(\mathrm{J}-1)$ & $\mathrm{MP} 2$ & $\sigma_{\mathrm{xy}}+n \sigma_{\mathrm{dxy}}+n K \sigma_{\text {exy }}$ \\
Error among hill (d) & $\mathrm{IJ}(\mathrm{K}-1)$ & $\mathrm{MP} 3$ & $\sigma_{\mathrm{xy}}+n \sigma_{\mathrm{dxy}}$ \\
Error within hill (u) & $\mathrm{IJK}(\mathrm{n}-1)$ & PM4 & $\sigma_{\mathrm{xy}}$ \\
\hline
\end{tabular}

*J = number of replications; $\mathrm{I}=$ number of progenies; $\mathrm{K}=$ number of hills/plot; $\mathrm{n}=$ harmonic average of the number of tubers/hill.

\section{RESULTS AND DISCUSSION}

In average, the tubers showed a slightly long shape, because of the ratio between length and larger diameter was 1.297 and with the smaller diameter was 1.512 (Table 3). Therefore, tubers were $29.7 \%$ longer than the larger diameter and $51.2 \%$ longer than the smaller diameter. These results are important for selection; because of tuber shape is an indication of cultivar purpose. Cultivars with long tubers are suitable for french fry processing and round tubers for chip processing. In this case, there was variation for tuber shape, being predominant the long-shape type.

The variance among progenies was significant at 5\% level for all individual and ratios between tuber traits (Table 3), with the exception of the smaller diameter. Also, there were differences among hill variance estimations for individual and ratios of a given trait. The mean square errors among hills were higher than among plots for all evaluated traits.

Table 3. Summary of the analysis of variance, estimates of the components of variance and heritability for length (L), larger (LD) and smaller diameter (SD), and fresh weight (FW) of potato tubers and estimates of linear correlation coefficients between first and second generations $\left(\mathrm{r}_{12}\right)$, and second and third generations $\left(\mathrm{r}_{23}\right)$

\begin{tabular}{lccccccc}
\hline Sources of variation & df & L & LD & SD & FW & L/LD & L/SD \\
\cline { 2 - 8 } & \multicolumn{7}{c}{ Mean squares } \\
Progeny & 8 & $781.23^{*}$ & $337.76^{*}$ & 188.60 & $3307.92^{*}$ & $0.2939^{*}$ & $0.4818^{*}$ \\
Error among plot & 9 & 138.55 & 106.64 & 90.42 & 689.79 & 0.0513 & 0.0953 \\
Error among hill & 31 & 282.62 & $155.71^{*}$ & 102.42 & 1375.82 & $0.0885^{*}$ & $0.2011^{*}$ \\
Error within hill & 142 & 224.47 & 103.67 & 73.50 & 957.71 & 0.0382 & 0.0926 \\
Average & - & 48.32 & 37.25 & 31.95 & 40.41 & 1.297 & 1.512 \\
CV (\%) & - & 31.0 & 27.3 & 26.8 & 76.5 & 15.0 & 19.9 \\
\hline & & \multicolumn{7}{c}{ Estimates of variance } \\
Progeny & $\sigma_{\mathrm{g}}^{2}$ & 52.94 & 19.04 & 8.09 & 215.66 & 0.020 & 0.0318 \\
Error among plot & $\sigma_{\mathrm{e}}^{2}$ & $0^{+}$ & 0 & 0 & 0 & 0 & 0 \\
Error among hill & $\sigma_{\mathrm{d}}^{2}$ & 24.03 & 21.50 & 11.95 & 172.77 & 0.021 & 0.0448 \\
Error within hill & $\sigma^{2}$ & 224.47 & 103.67 & 73.5 & 957.71 & 0.038 & 0.0926 \\
\hline & & \multicolumn{7}{c}{ Estimates of heritability } & \\
Clone selection & $\left(\mathrm{h}_{\mathrm{i}}^{2}\right)$ & 0.19 & 0.14 & 0.09 & 0.18 & 0.27 & 0.21 \\
Progeny selection & $\left(\mathrm{h}_{\mathrm{m}}^{2}\right)$ & 0.82 & 0.68 & 0.52 & 0.79 & 0.83 & 0.80 \\
Correlation ( $\left.\mathrm{r}_{12}\right)$ & $\left(\mathrm{h}_{\mathrm{m}}^{2}\right)$ & 0.39 & 0.43 & 0.48 & 0.44 & $0.59 *$ & 0.32 \\
Correlation $\left(\mathrm{r}_{23}\right)$ & $\left(\mathrm{h}_{\mathrm{m}}^{2}\right)$ & $0.56^{*}$ & 0.45 & 0.34 & $0.64 *$ & $0.83^{*}$ & $0.68^{*}$ \\
\hline
\end{tabular}

" Significant by F test at 5\% probability of error;

+ Negative estimate.
This resulted in negative estimation of variance components among plots. These negative estimations can be explained by the fact that potato is planted in hills and/or three-hill plot was not representative for this experiment. In this case, plot size of one hill would increase replication number and experimental precision (Barbin 1998).

Heritability estimates for selecting clones were low $\left(h_{i}^{2} \leq 0.27\right)$ (Table 3). However, heritability estimates for selecting progeny were high $\left(\mathrm{h}_{\mathrm{m}}^{2} \geq 0.50\right)$. In general, rations between traits had higher estimations of heritability than individual traits, which were expected, because of the lower experimental error. Some of the heritability values for selecting progeny $\left(h_{m}^{2}\right)$ estimated by components of variance were a little bit higher than the ones estimated by correlation between generations. As expected, the estimations of heritability also varied when data from different generations were correlated $\left(\mathrm{r}_{12}\right.$ or $\left.\mathrm{r}_{23}\right)$.

The heritability estimate for tuber fresh weight $\left(\mathrm{h}_{\mathrm{m}}^{2}=0.79\right)$ to select progeny was the same found by Rodrigues and Pereira (2003). We could not compare the heritability estimations of the other evaluated traits. However, we found different heritability estimations for other tuber traits. For reducing sugar content, the heritabilities varied from 0.32 (Salamoni et al. 2000) to 0.51 in spring and 0.73 in autumn (Chalá et al. 2001). For dry matter content, the heritabilities varied from 0.38 (Salamoni et al. 2000) to 0.72 (Rodrigues and Pereira 2003). Heritability estimates of 0.49 and 0.87 were found respectively for chip color and tuber number (Rodrigues and Pereira 2003). Heritability of 0.64 , for tuber size (Silva et al. 2008a), and between 0.49 and 0.69 , for skin smoothness (Silva et al. 2008b), were also estimated.

The estimation of heritability by correlation between generations $\left(r_{12}\right.$ and $\left.r_{23}\right)$ express the heritability $\left(h_{m}^{2}\right)$ for selecting progenies (Venkovsky and Barriga 1992, Bisognin and Douches 2002, Andreu 2005). In this work, we found similar estimations between second and third generations with the method of variance components in the third clone generation, with two replications of three-hill plots. This similarity of estimations 
between the two methods is very important, because we can get the necessary data set directly from the breeding program without any specific experiment, as necessary to estimate the components of variance.

The correlation coefficients between tuber shape and fresh weight were highly and directly associated (Table 4). Interesting is that high correlations between the traits were also found among hills, exactly the way we select clones in the first generation in the field. Therefore, we can establish an indirect selection program for these tuber traits. The smallest correlation (0.348) was between length and smaller diameter, which is also important. Therefore, we would get selection gain in this group of clones for both long shape, for french fry processing, and round shape, for chip processing, cultivars.

The results of this work indicated that fresh weight and tuber shape traits can be selected in the first generaTable 4. Mean products of the covariance analysis, estimates of covariance and coeficients of correlation between length (L), larger diameter (LD) and smaller diameter (SD) of potato tubers

\begin{tabular}{|c|c|c|c|c|}
\hline Sources of variation & df & L $x$ LD & L x SD & $\mathbf{L} \times \mathbf{F W}$ \\
\hline & \multicolumn{4}{|c|}{ Mean products } \\
\hline Progeny & 8 & 386.84 & 265.86 & 1328.30 \\
\hline Error among plot & 18 & 91.13 & 83.28 & 249.96 \\
\hline Error among hill & 23 & 170.65 & 122.01 & 558.29 \\
\hline \multirow[t]{2}{*}{ Error within hill } & 141 & 137.52 & 107.73 & 416.58 \\
\hline & \multicolumn{4}{|c|}{ Components of covariance } \\
\hline Progeny & - & 24.36 & 15.04 & 88.82 \\
\hline Error among plot & - & -13.10 & -6.38 & -50.80 \\
\hline Error among hill & - & 13.69 & 5.90 & 58.56 \\
\hline \multirow[t]{2}{*}{ Error within hill } & - & 137.52 & 107.73 & 416.58 \\
\hline & & \multicolumn{3}{|c|}{ Coeficients of correlation } \\
\hline Progeny & & 0.767 & 0.727 & 0.831 \\
\hline Error among plot & & - & - & - \\
\hline Error among hill & & 0.602 & 0.348 & 0.909 \\
\hline Error within hill & & 0.901 & 0.839 & 0.898 \\
\hline
\end{tabular}

tion of the potato breeding program. This generation is usually conducted in single-hill plots, the same way we also conducted the second generation. As the heritability estimations based upon data set from second and third generations $\left(\mathrm{r}_{23}\right)$ were quite high $\left(\mathrm{h}_{\mathrm{m}}^{2} \geq 0.32\right)$, the gain from selection would be also high in the single-hill plot generation. The correlation analysis between generations gave a good estimation of the heritability, similar to the variance components. Therefore, data set from field evaluations of a high number of clones can be used to estimate the heritability and the gain from selection to identify the best breeding strategy. Considering that heritability estimations for clone selection were smaller than progeny selection, we should select the best progeny and discard only the less desirable clones in each selected one. As tuber shape and fresh weight were highly and directly correlated, applying selection for any of these characters would result in genetic gain for the others, which facilitates the breeding process. The breeding gain can be maximized combining the selection for tuber shape and fresh weight among and within progeny to early discard undesirable clones.

\section{CONCLUSIONS}

Potato tuber shape and fresh weight have higher heritability estimations for progeny selection. These traits are also highly correlated and indicated for indirect selection. The breeding gain can be maximized combining the selection among and within progeny to early discard undesirable clones.

\section{AKNOWLEGMENTS}

To CNPq for scholarship and financial support to the Potato Breeding and Genetics Program.

\title{
Herdabilidade e correlação entre caracteres de tubérculo de batata
}

\begin{abstract}
Resumo - Os objetivos deste trabalho foram estimar os componentes de variância, covariancia e herdabilidade dos caracteres de formato e massa fresca de tubérculos de batata e estimar a correlação entre esses caracteres nas primeiras gerações clonais. Foram avaliados o comprimento, diâmetro maior e menor e massa fresca dos tubérculos-semente e daqueles colhidos de clones de nove progênies. Em média, os tubérculos das progênies foram alongados, pois apresentaram uma relação entre o comprimento com o maior diâmetro de 1,30 e com o menor diâmetro de 1,51. As estimativas de herdabilidade para a seleção de progênies foram altas, enquanto que para a seleção de clones dentro de progênies foram baixas. As estimativas de herdabilidade obtidas com a correlação entre gerações clonais foram altas e similares as de médias de progênies. Os caracteres de formato e tamanho de tubérculo são altamente correlacionados e ganho genético pode ser maximizado com a seleção entre e dentro de progênies.
\end{abstract}

Palavras-chave: Solanum tuberosum L., variância genética, ganho de seleção, melhoramento de batata. 
DA Bisognin et al.

\section{REFERENCES}

Andreu MA (2005) Associação entre características agronômicas da batata nos plantios de primavera e outono no Rio Grande do Sul. Ciência e Agrotecnologia 29: 925-929.

Barbin D (1998) Componentes de variância: teoria e aplicações. $2^{\text {nd }}$ ed., FEALQ, Piracicaba, 120p.

Benedetti M, Bisognin DA, Segatto FB, Costa LC, Bandinelli MG and Brackmann A(2005) Quebra de dormência de minitubérculos de batata. Ciência Rural 35: 31-38.

Beukema HP and Van Der Zaag DE (1990) Introduction to potato production. PUDOC, Wageningen, 208p.

Bisognin DA (2003) Melhoramento da batata para resistência a doenças. In Pereira AS and Daniels J O cultivo da batata na região sul do Brasil. Embrapa Informação Tecnológica, Brasília, p. 125-142.

Bisognin DA and Douches DS (2002) Early generation selection for potato tuber quality in progeny of late blight resistant parents. Euphytica 127: $1-9$.

Bisognin DA, Centenaro R and Missio EL (1998) Uso do ácido giberélico na quebra de dormência e de dominância apical em batata. Ciência Rural 28: 205-213.

Bisognin DA, Freitas ST, Brackmann A, Andriolo JL, Pereira EIP, Muller DR and Bandinelli MG (2008) Envelhecimento fisiológico de tubérculos de batata produzidos durante o outono e a primavera e armazenados em diferentes temperaturas. Bragantia 67: 59-65.
Chalá CSA, Pereira AS, Campos AD, Viégas J and Salamoni AT (2001) Variabilidade genética para teor de açúcares redutores em batatas silvestres que ocorrem no sul do Brasil. Ciência Rural 31: 43-47.

Embrapa (1997) Ambiente de software NTIA, versão 4.2.2: manual do usuário - ferramental estatístico. Centro Nacional de Pesquisa Tecnológica em Informática para a Agricultura, Campinas, 258p.

Rodrigues AFS and Pereira AS (2003) Correlações inter e intragerações e herdabilidade de cor de chips, matéria seca e produção em batata. Pesquisa Agropecuária Brasileira 38: 599-604.

Salamoni AT, Pereira AS, Viégas J, Campos AD and Chalá CSA (2000) Variância genética de açúcares redutores e matéria seca e suas correlações com características agronômicas em batata. Pesquisa Agropecuária Brasileira 35: 1441-1445.

Silva GO, Pereira AS, Souza VQ, Carvalho FIF and Fritsche Neto R (2008a) Seleção para caracteres componentes de aparência e rendimento de tubérculo em plântulas de batata. Horticultura Brasileira 26: 325-329.

Silva GO, Pereira AS, Souza VQ, Carvalho FIF and Vieira EA (2008b) Qualidade de película de famílias clonais de batata. Bragantia 67: 639-648.

Thill CA and Peloquin SJ (1995) A breeding method for accelerated development of cold chipping clones in potato. Euphytica 84: 73-80.

Vencovsky R and Barriga P (1992) Genética biométrica no fitomelhoramento. Revista Brasileira de Genética, Ribeirão Preto, 496p. 